\title{
Az extrém kis születési súlyú koraszülöttek fejlődésének követése az óvodáskor végéig a perinatalis szövődmények tükrében
}

\author{
Nagy Anett ${ }^{1,2,5}$ - Beke Anna Mária dr. ${ }^{5}$ - Cserjési Renáta dr. ${ }^{3}$ \\ Gráf Rózsa ${ }^{6}$ - Kalmár Magda dr. ${ }^{4}$ \\ Eötvös Loránd Tudományegyetem, ${ }^{1}$ Bárczi Gusztáv Gyógypedagógiai Kar, \\ Atipikus Viselkedés és Kogníció Gyógypedagógiai Intézet, ${ }^{2}$ Pszichológiai Doktori Iskola, \\ ${ }^{3}$ Pedagógiai és Pszichológiai Kar, Affektív Pszichológia Tanszék, \\ ${ }^{4}$ Pedagógiai és Pszichológiai Kar, Fejlődés- és Klinikai Gyermekpszichológia Tanszék, Budapest \\ ${ }^{5}$ Semmelweis Egyetem, Általános Orvostudományi Kar, I. Szülészeti és Nőgyógyászati Klinika, Budapest \\ ${ }^{6}$ Szent János Kórház és Észak-budai Egyesített Kórházak, Gyermek és Ifjúságpszichiátriai Rehabilitációs Osztály, \\ Budapest
}

\begin{abstract}
Bevezetés: Az orvostudomány fejlődésének eredményeként az 1000 gramm alatti születési súlyú koraszülöttek túlélése egyre magasabb, fejlődésük hosszú távú következményeiről azonban ellentmondásosak a kutatási eredmények. Célkitüzés: Súlyos idegrendszeri károsodástól mentes, extrém kis születési súlyú koraszülötteknek az iskoláskor eléréséig tartó követése során gyüjtött adataink segítségével ennek a jelentős rizikócsoportnak a fejlődési mechanizmusához igyekeztünk közelebb jutni. Munkánkkal a fejlődés rizikótényezőinek megértéséhez és a fejlődés előrejelzését szolgáló modell kidolgozásához szeretnénk hozzájárulni.

Módszer: Súlyos idegrendszeri károsodástól mentes, extrém kis születési súlyú koraszülöttek $(\mathrm{n}=34)$ longitudinális vizsgálata történt, 1 és 2 éves korban pszichomotoros fejlődési skálával, majd 5 és 6 éves kor között intelligenciateszttel. A fejlődés háttértényezőinek elemzése kiterjedt a perinatalis szövődményekre és az anya iskolai végzettségére is. Eredmények: Az extrém kis születési súlyú koraszülöttek csoportszinten egyik életkori mérésnél sem mutattak fejlődési elmaradást: a fejlődési hányados átlaga 1 és 2 éves korban 98,6, illetve 106,6, az 5-6 éves kori verbális és performációs IQ 101,4, illetve 92,9. A szórás és a szélső értékek azonban nagy egyéni különbségekre utalnak. A kisgyermekkori fejlődésre a születési súly, a bronchopulmonalis dysplasia, a méhen belüli növekedési retardáció, a nem és az anya iskolai végzettsége volt a leginkább hatással. A lányok jobban teljesítettek a nyelvi fejlődést mérő skálában, mint a fiúk. A verbális intelligenciát az agykamrai vérzés, míg a performációs képességeket az intrauterin retardáció befolyásolta hátrányosan.

Következtetések: Vizsgálataink szerint az extrém kis születési súlyú koraszülötteknek jó esélyük van a megfelelő értelmi fejlődésre, azonban az egyéni fejlődési perspektívákat sok tényező befolyásolja, melyek hatása területfüggő. A kisgyermekkori fejlődés szignifikáns előrejelzője a későbbi intelligenciának; ez az összefüggés közepes mértékű, a fejlődés üteme bármikor megváltozhat. A „mozgó rizikó” jelensége felhívja a figyelmet a koraszülöttek hosszú távú követésének jelentőségére.
\end{abstract}

Orv Hetil. 2018; 159(41): 1672-1679.

Kulcssszavak: koraszülött, extrém kis születési súly, perinatalis szövődmény, fejlődési skála, intelligencia

Follow-up study of extremely low birth weight preterm infants to preschool age in the light of perinatal complications

Introduction: Owing to the rapid progress of the medical science and technology, the chances of survival of the extremely low birth weight $(<1000 \mathrm{~g})$ preterm babies have dramatically improved. Nevertheless, the research findings on their long-term developmental outcome are inconsistent. 
Aim: Our study has attempted to contribute to the understanding of the developmental mechanisms in the extremely low birth weight preterm infants and to the prediction of the developmental outcomes taking into account of the risk factors of development.

Method: 34 preterm children who were free of any major central nervous system injury were followed up from one to 5-6 years of age. The psychomotor development of the infants was assessed at 1 and 2 years of age and, at 5-6 years of age, intelligence tests were administered to the children. Perinatal and environmental factors were included in the data analysis.

Results: The extremely low birth weight preterm children as a group displayed no developmental delay at any of the measurement points. The mean developmental quotients were 98.6 and 106.6 at ages 1 and 2 years, respectively. At 5-6 years of age, the mean verbal IQ was 101.4, while the mean performance IQ was 92.9. Behind the group means there was a wide range of individual variations. The most powerful contributors to the developmental outcomes were birth weight, bronchopulmonary dysplasia, intra-uterine growth retardation, gender, and maternal education. The girls had a significant advantage over the boys in language development. Verbal intelligence was hampered by intracranial hemorrhage, while intrauterine growth restriction had a similar effect on the performance IQ.

Conclusions: Our results suggest that even the extremely preterm infants may have rather good chances of satisfactory mental development. However, the individual developmental prospects are influenced by a great number of domain-specific risk- and protective factors. Although at a group-level, infant psychomotor development is a significant predictor of later intelligence quotient, the rate of development may change at any age. The phenomenon of "moving risk" underscores the importance of the long-term follow-up of preterm infants.

Keywords: preterm, extremely low birth weight, perinatal complication, psychomotor development, intelligence, follow-up

Nagy A, Beke AM, Cserjési R, Gráf R, Kalmár M. [Follow-up study of extremely low birth weight preterm infants to preschool age in the light of perinatal complications]. Orv Hetil. 2018; 159(41): 1672-1679.

(Beérkezett: 2018. május 24.; elfogadva: 2018. június 26.)

\section{Rövidítések}

$\mathrm{BPD}=($ bronchopulmonary dysplasia $)$ bronchopulmonalis dysplasia; $\mathrm{BQ}=$ beszédalskála-hányados; $\mathrm{CP}=$ (cerebral palsy) cerebralis paresis; ELBW = (extremely low birth weight $)$ extrém kis születési súly; FQ = fejlődési hányados; $\mathrm{IVH}=$ (intraventricular hemorrhage) agykamrai vérzés; $\mathrm{KQ}$ = koordinációalskálahányados; LBW = (low birth weight $)$ alacsony születési súly; $\mathrm{MR}=$ mágneses rezonancia; PerfQ $=$ performációs hányados; $\mathrm{PQ}=$ nagymozgásalskála-hányados; $\mathrm{PVL}=($ periventricular leucomalacia) periventricularis leukomalacia; RDS $=($ respiratory distress syndrome) respirációsdistressz-szindróma; ROP $=($ retinopathy of prematurity) koraszülöttek retinopathiája; $\mathrm{SD}=$ (standard deviation) standard eltérés; SGA $=$ (small for gestational age) méhen belüli növekedési retardáció; $S z Q=$ szociabilitásalskála-hányados; VLBW = (very low birth weight) igen alacsony születési súly; VQ = verbális hányados

Az elmúlt 10 évben örvendetes javulás észlelhetô a csecsemőhalandóságban (az első 365 napon belül az 1000 élveszülöttre vonatkoztatott elhalt csecsemők száma 2006-tól 5,6 ezrelékról 2016-ra 3,9 ezrelékre csökkent). A koraszülési ráta nem változott, az élveszülöttek 8-10\%-a korábban jön a világra. Az évi 93-94 ezer újszülöttből évente körülbelül 8000-9500-an koraszülöttek. A KSH adatai szerint hazánkban 2016-ban 93063 élveszülésből 8339 koraszülött volt [1]. A túlélés javulásával továbbra is döntő kérdés a túlélők életminősége, mely a családokon keresztül az egész társadalmat érinti. Minél korábban és minél kisebb születési súllyal jönnek a világra, a koraszülöttség annál nagyobb rizikótényezőt jelent az újszülöttek számára [2]. Hazánkban a neonatalis intenzív osztályokon ápolt újszülöttek $0,7 \%$-a 500 gramm alatti, 8\%-uk pedig 500-999 gramm születési súly között jött a világra [3].

A születési súly alapján történő kategorizálás szerint a következő csoportokat különböztetik meg: az 1000 gramm alattiakat extrém vagy igen-igen kis súlyú (extremely low birth weight, ELBW), az 1000-1499 gramm közöttieket igen kis súlyú (very low birth weight, VLBW), az 1500-2499 gramm közöttieket pedig kis súlyú (low birth weight, LBW) újszülötteknek nevezik [4].

A koraszülöttek éretlenségük miatt a perinatalis időszakban hajlamosabbak olyan megbetegedésekre, amelyek a légzőszervet (respirációsdistressz-szindróma, RDS), az idegrendszert és az érzékszerveket érintik. Az agykamrai vérzés (intraventricularis haemorrhagia, IVH) valószínűsége extrém kis súlyúak esetében $50 \%$ [5]. Az IVH súlyos formája (III. és IV. stádiumú vérzés) a nagy fokban éretlen újszülötteknél gyakoribb: a 24. gesztációs héten $39,9 \%$, a 26 . gesztációs héten $24 \%$, míg a 28 . héten $9,7 \%$ [6]. A súlyos stádiumú agykamrai vérzések után 50\%-ban alakul ki posthaemorrhagiás hydrocephalus [7]. Ennek megoldása mútéti. A periventricularis leukomalacia (PVL) koraszülötteknél jellegzetes fehérállományi sérülés, amely esősorban a méhen belül, illetve ritkán a megszületés után kialakult tartós agyi keringészavar (ischaemia) következménye. Cerebralis paresishez (CP) és az érintett agyterületektől függően változó kombinált 
tünetcsoportokhoz vezet. Az ELBW-csoportban a CP előfordulása 12\% [8]. A PVL diagnózisa bizonytalan, mert a diffúz formát csak MR-vizsgálattal lehet igazolni, az ultrahangvizsgálattal sok esetben álnegatív eredményt kapunk [9]. Az extrém kis súlyú koraszülötteknél az idegrendszeri görcstevékenység lefolyása a legtöbbször nem tartós, túlnyomó részük nem epilepsziás eredetű; postnatalis epilepszia újszülöttkori görcsök után 10 $15 \%$-ban fordul elő [10].

Perinatalis légzőszervi szövődményként jelenhet meg a bronchopulmonalis dysplasia (BPD), amelynek prevalenciája extrém kis súlyú koraszülöttek esetén a 30\%-ot is meghaladhatja [11]. Az érzékszervi szövődmények közül a retinopathia prematurorum (ROP) valamelyik stádiuma, mely az extrém kis súlyúak 15\%-ában alakul ki, sok esetben szemészeti beavatkozással gyógyítható. Bár bizonyos fokú látáscsökkenés és myopia fennmaradhat, a látásvesztés a legtöbb esetben elkerülhető [7].

A koraszülöttek idegrendszeri fejlődése eltér az időre született újszülöttekétől [12,13]. Még enyhe rizikó esetén is eltéréseket találtak a fehér- és a szürkeállomány struktúrájában, vékonyabb az entorhinalis kéreg [14] és a corpus callosum [15], kisebb a hippocampalis [16] és a kisagyi térfogat [17].

A súlyos perinatalis szövődményektől mentes ELBWkoraszülöttek a fejlődési skálákban alacsonyabb értéket értek el, mint időre született társaik, bár ez a teljesítmény a normálövezeten belül helyezkedett el [18-20]. Az életkor növekedésével egyre kifejezettebb a lemaradás a fejlődés terén $[21,22]$, ami alacsonyabb teljesítményt okoz az intelligenciatesztekben az időre született kontrollcsoporthoz képest [23-25].

Számos kutatás célozta meg a koraszülöttcsoporton belüli fejlődési eltérések hátterének feltárását. Az ELBWkoraszülöttek esetében is meghatározónak bizonyult a születési súly és a gesztációs kor [26, 27], ezeken túl a különböző perinatalis szövődmények, mint az IVH [28, 29], a BPD [30-32] és a ROP [31]. Az intrauterin retardáció (small for gestational age, SGA) fejlődésre gyakorolt hatásáról ellentmondásosak a kutatások. Kato és mtsai az SGA negatív hatását csak a 28. gesztációs hétnél korábban született koraszülöttek esetében találták jelentősnek [33], míg Gortner kutatócsoportja nem talált különbséget az SGA- és nem SGA-csoport között [34]. Fontos befolyásoló tényezőnek bizonyult a nem szerepe, amely a fiúk hátrányát mutatta $[27,28,35,36]$, illetve a család szocioökonómiai státusza is [29], ahol az anya magasabb iskolai végzettségét jelölik meg kedvezőbb feltételként $[18,28,34]$.

\section{Módszer}

\section{Vizsgált személyek}

A vizsgálati minta a Semmelweis Egyetem I. Szülészeti és Nőgyógyászati Klinikájának koraszülött-utánvizsgálatán 1998 és 2010 között részt vett, extrém kis súlyú kora- szülöttek közül került ki. Olyan koraszülötteket vizsgáltunk, akiknek nem volt központi idegrendszeri eredetú tartós mozgássérülésük, értelmi fogyatékosságuk, látásvesztésük, halláskárosodásuk, nehezen kezelhető epilepsziájuk. A mintába való bekerülés feltétele az utánvizsgálatokon való rendszeres megjelenés (korrigált 1-3-6-9-12-18-24 hónapos korban, majd évente), továbbá a fejlődési skálával való vizsgálhatóság volt. Eszerint 34 ELBW-koraszülött fejlődésének adatait dolgoztuk fel. A mintánkba bevont gyermekek átlagosan a 27 . hétre $(\mathrm{SD}=1,85 ; 24-31$. hét) és átlagosan 839 grammal $(S D=148,68 ; 480-990$ gramm) születtek, közülük 12 fiú és 22 lány. A gesztációs kor, a születési súly és a perinatalis szövődmények nemek szerinti megoszlása az 1. táblázatban látható.

Az agykamrai vérzés (I-II. stádium) és az intrauterin retardáció (SGA) gyakrabban érintette a fiúkat, míg a BPD és a ROP a lányokat (a különbségek nem szignifikánsak). A többi perinatalis mutató megoszlása a nemek között egyenletesnek mondható.

1. táblázat A gesztációs kor, a születési súly és a perinatalis problémák előfordulása

\begin{tabular}{|c|c|c|c|}
\hline & Teljes minta & Fiú & Lány \\
\hline $\mathrm{n}$ & 34 & 12 & 22 \\
\hline Gesztációs kor & 27 hét & 27 hét & 27,2 hét \\
\hline Születési súly & $839 \mathrm{~g}$ & $868 \mathrm{~g}$ & $823 \mathrm{~g}$ \\
\hline $\begin{array}{l}\text { Bronchopulmonalis dysplasia } \\
\text { (BPD) }\end{array}$ & $32,4 \%$ & $25 \%$ & $36,4 \%$ \\
\hline Agykamrai vérzés (IVH) & $38,2 \%$ & $58,3 \%$ & $27,3 \%$ \\
\hline $\begin{array}{l}\text { Retinopathia prematurorum } \\
\text { (ROP) }\end{array}$ & $70,6 \%$ & $66,7 \%$ & $72,7 \%$ \\
\hline $\begin{array}{l}\text { Méhen belüli növekedési } \\
\text { retardáció (SGA) }\end{array}$ & $32,4 \%$ & $41,7 \%$ & $27,3 \%$ \\
\hline
\end{tabular}

\section{A vizsgálatok menete}

Az utánvizsgálatok alkalmával, a fejlődésneurológiai vizsgálatokon felül, három alkalommal került sor a fejlődés mérésére a Brunet-Lèzine-féle pszichomotoros fejlődési skálával, majd az Óvodás Wechsler Intelligenciateszttel (OWI). A vizsgálat ideje alatt a csecsemő- és kisgyermekkori fejlődés mérésére a Brunet-Lèzine-skála volt az egyetlen, magyar populációra adaptált és standardizált eljárás, amely mind hazai [37], mind külföldi kutatások [38] szerint bizonyos mutatóiban korrelál az újabban elterjedt Bayley-féle fejlődési skálával.

Kiválasztottunk három életkort, amelyeket metodikai és prognosztikai szempontból relevánsnak feltételeztünk: a gyermekek korrigált 11-14 hónapos korában (a későbbiekben 1 éves kori) (átlag: 12,40; SD = 1,07) és korrigált 23-26 hónapos korában (a későbbiekben 2 éves kori) (átlag: 24,22; SD =1,05), illetve nem korrigált 5-6 éves kor között (átlag: 67,5; SD = 5,97). Az után- 
| A fejlődési mutatók: átlag, szórás, szélső értékek

\begin{tabular}{|c|c|c|c|c|c|c|}
\hline & Teljes & $=34)$ & & & Lány. & 22) \\
\hline Életkor & l év & 2 év & l év & 2 év & l év & 2 év \\
\hline Mutató & & & & & & \\
\hline Fejlődési hányados (FQ) & 98,6 & 105,6 & 92,6 & 102,7 & 101,9 & 107,1 \\
\hline & $(14,0)$ & $(10,8)$ & $(17,3)$ & $(12,8)$ & $(11)$ & $(9,5)$ \\
\hline & $66-123$ & $77-122$ & $66-120$ & $77-119$ & $80-123$ & $89-122$ \\
\hline Nagymozgásalskála-hányados (PQ) & 101,5 & 105,8 & 94,3 & 103,7 & 105,4 & 107 \\
\hline & $(18,9)$ & $(12,6)$ & $(19,9)$ & $(14,3)$ & $(17,5)$ & $(11,8)$ \\
\hline & $61-142$ & $80-132$ & $61-126$ & $81-132$ & $70-142$ & $80-125$ \\
\hline Koordinációalskála-hányados (KQ) & 96,9 & 104,9 & 91,2 & 101,7 & 100 & 106,5 \\
\hline & $(13,5)$ & $(13,5)$ & $(15,6)$ & $(17,2)$ & $(11,4)$ & $(11)$ \\
\hline & $67-121$ & $64-126$ & $67-115$ & $64-126$ & $79-121$ & $84-124$ \\
\hline Beszédalskála-hányados (BQ) & 96,9 & 102,4 & 88,7 & 92,7 & 101,5 & 107,7 \\
\hline & $(18,2)$ & $(18,6)$ & $(19,6)$ & $(21,2)$ & $(16,1)$ & $(14,9)$ \\
\hline & $61-129$ & $46-129$ & $61-126$ & $46-124$ & $73-129$ & $79-129$ \\
\hline Szociabilitásalskála-hányados (SzQ) & 100,2 & 106,4 & 95,8 & 101 & 102,6 & 109,4 \\
\hline & $(13,9)$ & $(14,9)$ & $(17,1)$ & $(20,4)$ & $(11,6)$ & $(10,3)$ \\
\hline & $69-129$ & $60-132$ & $69-126$ & $60-125$ & $85-129$ & $92-132$ \\
\hline
\end{tabular}

vizsgálatban való részvétel önkéntesen, időpont-egyeztetést követően történt. Azoknak a gyermekeknek az adatait vettük be az elemzésbe, akiknek tesztfelvételi időpontja a fenti életkori sávban volt, és mindhárom tesztfelvételkor értékelhető teljesítményt nyújtottak.

\section{Mutatók}

A Brunet-Lèzine-féle fejlődési kvóciens (FQ), valamint az alskálák eredményei: nagymozgás (PQ), koordináció $(\mathrm{KQ})$, beszéd (BQ) és szociabilitás $(\mathrm{SzQ})$. Az értékeléskor mindkét alkalommal a korrigált korral számoltunk. Az intelligenciateszt esetében a verbális kvóciens (VQ) és a performációs kvóciens (PerfQ) adatait vettük figyelembe.

Perinatalis jellemzők: gesztációs kor, születési súly, SGA, BPD, IVH, ROP. A perinatalis szövődmények esetében a diagnózis súlyossági fokozatot tartalmaz. Mivel a vizsgált mintánkban a súlyosabb kategóriák alacsony gyakorisággal fordultak elő (csak a ROP esetében volt 3-as stádium), az elemzésben a differenciálástól eltekintettünk, és csak a szövődmény meglétével vagy hiányával számoltunk. A PVL előfordulása (részben a diagnosztikai nehézségek miatt) olyan alacsony volt (3 fó; 8,8\%), hogy a statisztikai elemzésben nem volt használható. A szocioökonómiai tényezők közül az anya iskolai végzettségét vontuk be a vizsgálatba.

\section{Eredmények}

Az adatok feldolgozását az SPSS szoftver 22-es verziójának programcsomagjával (IBM, Armonk, NY, Amerikai Egyesült Államok) végeztük. A statisztikai próbák eredményeinél szignifikanciahatárként a $\mathrm{p}<0,05$ valószínúségi értéket fogadtuk el kétoldalúan értelmezve.
A vizsgálatok a tesztnormákhoz viszonyítva csoportszinten nem mutattak fejlődési elmaradást (2. és 3. táblá$z a t)$.

A lányok 1 éves korban $(\mathrm{M}=101,5, \mathrm{t}[32]=2,05$, $\mathrm{p}<0,05)$ és 2 éves korban $(\mathrm{M}=107,7, \mathrm{t}[32]=2,4 \mathrm{l}, \mathrm{p}=$ $0,02)$ is szignifikánsan jobb eredményt értek el a beszédfejlődést mérő skálában. A többi mutatóban nem volt különbség a két nem teljesítménye között.

A fejlődés háttértényezőinek tekintett perinatalis mutatókkal végzett egyváltozós elemzések eredményeiben sok szignifikáns összefüggést találtunk.

A születési súly szignifikánsan korrelál az 1 éves kori FQ-, KQ- és SzQ-értékekkel, azonban a 2 éves fejlődési mutatókkal már nem. A gesztációs kor egyik mutatóval sem korrelált szignifikánsan.

A mintát a perinatalis szövődmények szerint felosztva néhány esetben találtunk szignifikáns eltérést. A BPD által érintett gyermekek esetében alacsonyabb volt az 1 éves kori $S_{z Q}(M=93,27, S D=10,77 ; \mathrm{t}[31]=2,06$, $\mathrm{p}<0,05)$, a 2 éves kori FQ $(\mathrm{M}=99,9, \mathrm{SD}=11,76 ; \mathrm{t}[31]$ $=2,12, \mathrm{p}<0,05)$ és KQ $(\mathrm{M}=95,36, \mathrm{SD}=14,8 ; \mathrm{t}[31]=$ $3,13, p<0,01)$. Az agyvérzésen átesett gyermekek teljesítménye a VQ-ban volt gyengébb $(\mathrm{M}=92, \mathrm{SD}=20,33$; $\mathrm{t}[32]=2,45, \mathrm{p}=0,02)$. Az SGA-alcsoportban az 1 éves kori FQ $(M=91,36, S D=13,56 ; t[32]=2,21, \mathrm{p}=0,03)$,

3. táblázat |Az intelligenciateszt mutatói: átlag, szórás, szélső értékek

\begin{tabular}{lccc}
\hline Mutató & $\begin{array}{c}\text { Teljes minta } \\
(\mathrm{n}=34)\end{array}$ & $\begin{array}{c}\text { Fiúk } \\
(\mathrm{n}=12)\end{array}$ & $\begin{array}{c}\text { Lányok } \\
(\mathrm{n}=22)\end{array}$ \\
\hline Verbális hányados (VQ) & 101,4 & 96,9 & 103,9 \\
& $(18,9)$ & $(20,8)$ & $(15,7)$ \\
& $55-130$ & $55-130$ & $78-130$ \\
\hline Performációs hányados & 92,9 & 88,45 & 95,2 \\
(PerfQ) & $(17,1)$ & $(11,6)$ & $(19,1)$ \\
& $55-126$ & $70-108$ & $55-126$ \\
\hline
\end{tabular}




\begin{tabular}{|c|c|c|c|c|c|c|}
\hline \multirow[b]{2}{*}{ Mutató } & \multicolumn{3}{|l|}{ l év } & \multicolumn{3}{|l|}{2 év } \\
\hline & Magyarázó változó & $\begin{array}{l}\text { Korrigált } \\
\text { kumulált } \\
\mathrm{R}^{2}\end{array}$ & $\beta$-Súly & Magyarázó változó & $\begin{array}{l}\text { Korrigált } \\
\text { kumulált } \\
\mathrm{R}^{2}\end{array}$ & $\beta$-Súly \\
\hline \multirow[t]{2}{*}{ Fejlődési hányados (FQ) } & \multicolumn{6}{|l|}{ Születési súly } \\
\hline & & 0,12 & 0,38 & - & - & - \\
\hline $\begin{array}{l}\text { Nagymozgásalskála-hányados } \\
\text { (PQ) }\end{array}$ & Születési súly & 0,09 & 0,35 & $\begin{array}{l}\text { Bronchopulmonalis dysplasia } \\
\text { (BPD) }\end{array}$ & 0,10 & $-0,37$ \\
\hline \multirow[t]{3}{*}{$\begin{array}{l}\text { Koordinációalskála-hányados } \\
\text { (KQ) }\end{array}$} & \multirow[t]{3}{*}{ Születési súly } & \multirow[t]{3}{*}{0,13} & \multirow[t]{3}{*}{0,4} & $\begin{array}{l}\text { Bronchopulmonalis dysplasia } \\
\text { (BPD) }\end{array}$ & & $-0,49$ \\
\hline & & & & $\begin{array}{l}\text { Méhen belüli növekedési } \\
\text { retardáció (SGA) }\end{array}$ & 0,43 & $-0,45$ \\
\hline & & & & Anya iskolai végzettsége & & 0,39 \\
\hline \multirow{2}{*}{$\begin{array}{l}\text { Beszédalskála-hányados } \\
\text { (BQ) }\end{array}$} & \multirow[t]{2}{*}{-} & \multirow[t]{2}{*}{-} & \multirow[t]{2}{*}{-} & Nem & & 0,46 \\
\hline & & & & $\begin{array}{l}\text { Bronchopulmonalis dysplasia } \\
\text { (BPD) }\end{array}$ & 0,23 & $-0,33$ \\
\hline $\begin{array}{l}\text { Szociabilitásalskála-hányados } \\
(\text { SzQ) }\end{array}$ & Születési súly & 0,14 & 0,4 & Anya iskolai végzettsége & 0,17 & 0,44 \\
\hline
\end{tabular}

valamint a $P Q(M=91,36, S D=18,03 ; \mathrm{t}[32]=2,29$, $\mathrm{p}<0,05)$ alacsonyabb az intrauterin retardációt nem mutató gyermekekhez viszonyítva. A ROP nem jelentett fejlődési hátrányt.

A magyarázó változók egymásra gyakorolt hatásának kiszürése érdekében minden fejlődési mutatóra mint függő változókra többváltozós regressziós modellt állítottunk föl; a bevont független változók a nem, a gesztációs kor, a születési súly, a BPD, az IVH, a ROP, az SGA, valamint az anya iskolázottsága. A számításokat lépésenkénti eljárással végeztük, amely a lépéseket addig folytatja, amíg a modell korrigált $\mathrm{R}^{2}$-tel kifejezett magyarázó ereje növelhető egy újabb független változó beemelésével. Az erre vonatkozó eredményeket az 4. és az 5. táblázat mutatja.

A fenti eredmények értelmében a koraszülött fejlődésére az elsó életévben a születési súly kizárólagos hatást gyakorol. 2 éves korban a BPD három, az anya iskolai végzettsége kettő, míg az SGA és a nem egy-egy esetben mutatkozott jelentős befolyásoló tényezőnek. Az intelligenciateszt verbális skálájában nyújtott teljesítményre az IVH, míg a performációs alskálára az SGA tûnik befolyásoló tényezőnek.

Az adatok longitudinális összefüggéseit korrelációszámítással vizsgálva, a finommotorika $(\mathrm{r}[34]=0,4 ; \mathrm{p}<0,02)$ és a beszédfejlődés $(\mathrm{r}[34]=0,52 ; \mathrm{p}<0,002)$ mutatott közepes mértékü folyamatosságot. A VQ és a PerfQ minden 1 éves mutatóval, valamint a 2 éves BQ-val szignifikánsan korrelál, a VQ továbbá a 2 éves kori FQ-val, KQ-val és SzQ-val. A korrelációs együtthatók 0,34-0,88 között mozognak; ${ }^{1}$ ennek alapján ezek a közepes erősségü kapcsolatok.

\footnotetext{
${ }^{1}$ Helyszúke miatt a próbák eredményeit részletesen nem közöljük; az első szerzőnél minden adat hozzáférhető.
}

Összetartozó mintás t-próbát végeztünk annak megállapítására, hogy az első és a második életév között változott-e a fejlődés üteme. Minden mért mutatóban a 2 éves kori érték magasabb, a különbség az FQ esetében, továbbá egy alskálában, a KQ-ban éri el a szignifikanciaszintet (6. táblázat).

5. táblázat |A verbális hányados (VQ) és a performációs hányados (PerfQ) értékeit magyarázó tényezők

\begin{tabular}{llll}
\hline Mutató & Magyarázó változó & $\begin{array}{l}\text { Korrigált } \\
\text { kumulált } \\
\mathrm{R}^{2}\end{array}$ & $\beta$-Súly \\
\hline $\begin{array}{l}\text { Verbális } \\
\text { hányados (VQ) }\end{array}$ & $\begin{array}{l}\text { Agykamrai vérzés } \\
(\mathrm{IVH})\end{array}$ & 0,13 & $-0,4$ \\
$\begin{array}{l}\text { Performációs } \\
\text { hányados } \\
\text { (PerfQ) }\end{array}$ & $\begin{array}{l}\text { Méhen belüli } \\
\text { növekedési } \\
\text { retardáció (SGA) }\end{array}$ & 0,10 & $-0,36$ \\
\hline
\end{tabular}

6. táblázat |A két vizsgálat eredményeinek összehasonlítása

\begin{tabular}{|c|c|c|c|}
\hline \multirow[t]{2}{*}{ Mutató } & \multicolumn{2}{|c|}{$\begin{array}{l}\text { A két mérés közti } \\
\text { különbség } \\
\text { (2 éves-1 éves) }\end{array}$} & \multirow[t]{2}{*}{$\mathrm{t}$} \\
\hline & Átlag & SD & \\
\hline Fejlődési hányados (FQ) & 6,97 & 15,31 & $-2,65 *$ \\
\hline $\begin{array}{l}\text { Nagymozgásalskála-hányados } \\
\text { (PQ) }\end{array}$ & 4,35 & 20,98 & $-1,21$ \\
\hline $\begin{array}{l}\text { Koordinációalskála-hányados } \\
\text { (KQ) }\end{array}$ & 7,97 & 14,71 & $-3,16^{*}$ \\
\hline Beszédalskála-hányados (BQ) & 5,5 & 17,91 & $-1,79^{+}$ \\
\hline $\begin{array}{l}\text { Szociabilitásalskála-hányados } \\
(\text { SzQ) }\end{array}$ & 6,21 & 19,75 & $-1,83^{+}$ \\
\hline
\end{tabular}

${ }^{*} \mathrm{p}<0,05 ;{ }^{+} \mathrm{p}<0,10$ 


\section{Megbeszélés}

Kutatásunk célja az extrém kis súllyal született, súlyos idegrendszeri károsodástól mentes koraszülöttek fejlődésére ható tényezők megragadása volt. A fejlődési kimenetel mutatóiként több más kutatással ellentétben nem csupán a „megfelelő”, illetve „elmaradt” kategóriákat, hanem a fejlődési skála, valamint az intelligenciateszt számszerű eredményeit használtuk, ami finomabb elemzést és lineáris összefüggések feltárását is lehetővé tette.

Eredményeink szerint a vizsgált koraszülöttek fejlődési szintje a csoportátlagok tükrében minden mérésnél megfelelt az életkori normának (2. és 3. táblázat), megerősítve ezzel más kutatások tapasztalatait [16, 18, 22]. Reis és mtsai [35] eredményeivel ellentétben a fejlődés mutatói 1 és 2 éves kor között javultak (6. táblázat), és csoportszinten az 5-6 éves kori intelligenciaszint is megnyugtató.

Az átlagszámok mögött azonban az egyéni kimenetelek óriási változatossága húzódik meg, amint ez a szélső értékekből is nyilvánvaló. A hátteret a rendelkezésünkre álló perinatalis jellemzőkkel, valamint a szociális háttér mutatójaként az anya iskolázottságával elvégzett egyváltozós statisztikai próbák (korreláció és t-próba) szignifikáns eredményeinek többváltozós elemzésével igyekeztünk feltárni.

A többváltozós regressziós analízis eredményei csak részben illeszkednek a szakirodalomban található adatokhoz. Az eredmények közvetlen összevetése többnyire nem is lehetséges, mivel a vonatkozó kutatások alanyai azon túl, hogy extrém kis súlyú koraszülöttek, mind a perinatalis jellemzők, mind a szociális háttér tekintetében jelentősen különbözhetnek egymástól.

Az elemzés 1 éves korban a fejlődés globális mutatója és az összes részterület esetében egyaránt a születési súly kizárólagos jelentőségét emelte ki. Ez az eredmény részlegesen fedi a Xiong és mtsai által áttekintett kutatások tapasztalatait [26], amelyeket Salas és mtsai közleménye is megerősít [27]. A fenti két szerző a születési súly mellett a gesztációs idő hatását is hangsúlyozza, ez utóbbi azonban a mi adataink tükrében nem bizonyult meghatározónak. 2 éves korban változatosabb a kép. Az egyes részterületeken más-más háttértényezők befolyásolják a fejlődést, ebből adódhat, hogy az összesített fejlődési kvócienst egyetlen mutató sem magyarázza. Ugyanez érvényes az 5-6 éves korban mért intelligenciára. A leginkább a BPD okoz hátrányt (a 2 éves kori nagymozgás [PQ], koordináció [KQ], beszéd [BQ] területei). A koordináció magyarázatához hozzájárul az intrauterin fejlődési retardáció és az anya iskolai végzettsége is, a szociális területre (SzQ) pedig egyedül az anya iskolai végzettségének van hatása. A nem verbális intelligenciát illetően az intrauterin fejlődési retardáció, míg a verbális területen az agykamrai vérzés zavarja a fejlődést. A szakirodalomban gyakran lehet találkozni a lányok fejlődési előnyével [29, 30, 39]. Kutatásunkban ez a beszédfejlődés terén mutatkozott meg. Úgy tûnik, hogy a lányok ellenállóbbak az idegrendszert érintő károsító tényezőkkel szemben, de ennek háttere nem igazán tisztázott [40]. Az anya iskolai végzettsége általánosan használatos a család szocioökonómiai státuszának jellemzésére [18, 29], de a kognitív stimuláció mutatója is lehet [24]. Némileg meglepő - valószínúleg az idegrendszer fejlődését drasztikus károsodás híján is befolyásoló biológiai rizikó számlájára írható -, hogy e mutató 2 éves korban talált magyarázó szerepe nagyóvodás korra eltünt.

Feltételezzük, hogy további differenciáló tényező lehet a korai intervenció hatása. A vizsgált csoportunkban a neurohabilitáció, a Dévény Speciális manuális technika - Gimnasztika Módszer, valamint a korai fejlesztés fordult elő a leggyakrabban, azonban a módszerek és az alkalmazások heterogenitása miatt ezt a szempontot sajnos nem tudtuk az elemzésbe bevonni.

Az 1 és 2 éves kori fejlődési szint szignifikánsan összefügg az intelligenciatesztben 5-6 éves korban nyújtott teljesítménnyel. A korrelációk általában közepes mértéke óvatos előrejelzésre ad némi alapot, azonban arra utal, hogy tág tere van az egyéni fejlődésmenetek fluktuációjának. Ez egyes gyerekeknél jelentheti a fejlődés ütemének gyorsulását - 1 és 2 éves kor között a mutatók összehasonlítása szerint ez a többségre igaz -, másoknál viszont előre nem látható problémák jelentkezhetnek, ami abból fakad, hogy a fejlődés különbözô állomásain más-más rizikó- és protektív tényezők válnak hangsúlyossá.

\section{Következtetések}

A beiskolázásig folytatott longitudinális kutatásunk egyik legfóbb tanulsága az, hogy az 1000 gramm alatti születési súlyú koraszülötteknek is van esélyük a megfelelö értelmi fejlődéshez. A vizsgálatunkban követett extrém kis születési súlyú, drasztikus idegrendszeri károsodást nem szenvedett koraszülöttek fejlődése csoportszinten a normálövezetbe esik. Ugyanakkor nem szabad figyelmen kívül hagyni az óriási egyéni különbségeket. Az egyéni fejlődési perspektívákat igen sok tényező befolyásolja, amelyek hatása területfüggő. Eredményeink arra utalnak, hogy az intrauterin fejlődés zavara és a perinatalis szövődmények (adataink alapján elsősorban az agykamrai vérzés) olyan esetekben is hátráltathatják az értelmi fejlődést, amikor súlyos idegrendszeri károsodás nem diagnosztizálható.

A rizikómentesen született újszülöttekkel ellentétben az extrém kis születési súlyú koraszülöttek kisgyermekkori fejlődése szignifikáns előrejelzője az 5-6 éves kori intelligenciaszintnek. Az összefüggések azonban többnyire nem túl erősek, csupán közepes mértéküek, ami arra hívja fel a figyelmet, hogy a fejlődés üteme bármikor változhat. Az 1 és 2 éves kori fejlődési mutatók összehasonlítása a koraszülötteknél gyakran tapasztalt felzárkózási tendenciát [19] támasztja alá. Ugyanakkor az is előfordul, hogy a problémamentesen induló koraszülött fejlődésében a későbbiekben mutatkozik intervenciót 
igénylő zavar. A szakirodalomban ez a jelenség a „mozgó rizikó" nevet kapta, amely fóként olyan élethelyzetekben fenyeget, amelyek kihívások elé állítják a gyermeket [23]. Mindebből azt a következtetést vonhatjuk le, hogy a koraszülöttek hosszú távú utánkövetése nagyon fontos olyan esetekben is, amikor a korai fejlődés megnyugtatónak mutatkozik.

Anyagi támogatás: A szerzők anyagi támogatásban nem részesültek.

Szerzői munkamegosztás: N. A.: Adatgyüjtés, adatelemzés, szakirodalmi feldolgozás, statisztikai elemzés, szövegezés. B. A. M., Cs. R., G. R.: Szakirodalmi feldolgozás, adatelemzés, szövegezés. K. M.: Adatelemzés, szakirodalmi feldolgozás, statisztikai elemzés, szövegezés. A cikk végleges változatát valamennyi szerző elolvasta és jóváhagyta.

\section{Érdekeltségek: A szerzőknek nincsenek érdekeltségeik.}

\section{Köszönetnyilvánítás}

Köszönettel tartozunk Dr. Rigó János egyetemi tanárnak, a Semmelweis Egyetem, I. Szülészeti és Nőgyógyászati Klinika igazgatójának, aki támogatásával segítette kutatásunkat, és biztosította számunkra a munka elvégzésének feltételeit.

\section{Irodalom}

[1] Hungarian Central Statistical Office. Vital Statistics, 2016. [Központi Statisztikai Hivatal. Népmozgalom, 2016.] Statisztikai Tükör, April 21, 2017. [Hungarian]

[2] Varga P, Berecz B, Pete B, et al. Trends in mortality and morbid ity in infants under 500 grams birthweight: observations from our Neonatal Intensive Care Unit (NICU). Med Sci Monit. 2018; 24: 4474-4480.

[3] Kereki J. Issues of early childhood intervention: regional appraisal of the situation for the foundation of an institutional network of early childhood intervention. [A kora gyermekkori intervenció problématerületei: regionális helyzetértékelés a kora gyermekkori intervenciós intézményrendszer hálózatos fejlesztésének megalapozásához.] Educatio, 2012. [Hungarian]

[4] Szabó I. Pathological labor and delivery. In: Papp Z. (ed.) Book of obstetrics and gynaecology. [Kóros vajúdás és szülés. In: Papp Z. (szerk.) A szülészet-nőgyógyászat tankönyve.] Semmelweis Kiadó, Budapest, 2002; pp: 406-502. [Hungarian]

[5] Balla Gy, Szabó M. Chronic morbidities of premature newborns. [Koraszülöttek krónikus utóbetegségei.] Orv Hetil. 2013; 154: 1498-1511. [Hungarian]

[6] Ertl T. Care for the preterm and small-for-gestational-age newborns. Limit of viability. Early and long-term sequelae. In: Papp Z. (ed.) Handbook of perinatology. [A kora- és retardált újszülött ellátása. Az életképesség határa. Korai és hosszú távú következmények. In: Papp Z. (szerk.) A perinatológia kézikönyve.] Medicina Könyvkiadó, Budapest, 2016; pp. 387-400. [Hungarian]

[7] Fox G, Hoque N, Watts T. Oxford handbook of neonatology. [A neonatológia Oxford kézikönyve.] Kadix Press, Budapest, 2012. [Hungarian]
[8] Vohr BR, Msall ME, Wilson D, et al. Spectrum of gross motor function of extremely low birth weight children with cerebral palsy at 18 months of age. Pediatrics 2005; 116: 123-129.

[9] Mirmiran M, Barnes PD, Keller K, et al. Neonatal brain magnetic resonance imaging before discharge is better than serial cranial ultrasound in predicting cerebral palsy in very low birth weight preterm infants. Pediatrics 2004; 114: 992-998

[10] Beke A. Neonatal seizures. In: Papp Z. (ed.) Handbook of perinatology. [A görcsölő újszülött. In: Papp Z. (szerk.) A perinatológia kézikönyve.] Medicina Könyvkiadó, Budapest, 2016; pp. 197-210. [Hungarian]

[11] Walsh MC, Szefler S, Davis J, et al. Summary proceedings from Bronchopulmonary Dysplasia Group. Pediatrics 2006; 117: 5256.

[12] Patra K, Wilson-Costello D, Taylor HG, et al. Grades I-II intraventricular hemorrhage in extremely low birth weight infants: effects on neurodevelopment. J Pediatr. 2006; 149: 169-173.

[13] Bolisetty S, Dhawan A, Abdel-Latif M, et al. Intraventricular hemorrhage and neurodevelopmental outcomes in extreme preterm infants. Pediatrics 2014; 133: 55-62.

[14] Skranes J, Løhaugen GC, Evensen KA, et al. Entorhinal cortical thinning affects perceptual and cognitive functions in aldolescents born preterm with very low birth weight (VLBW). Early Hum Dev. 2012; 88: 103-109.

[15] Feldman HM, Lee ES, Yeatman JD, et al. Language and reading skills in school-aged children and adolescents born preterm are associated with white matter properties on diffusion tensor imaging. Neuropsychologia 2012; 50: 3348-3362.

[16] Beauchamp MH, Thompson DK, Howard K, et al. Preterm infant hippocampal volumes correlate with later working memory deficits. Brain 2008; 131: 2986-2994.

[17] De Kieviet JF, Zoetebier L, Van Elburg RM, et al. Brain development of very preterm and very low-birthweight children in childhood and adolescence: meta-analysis. Dev Med Child Neurol. 2012; 54: 313-323.

[18] Kumar P, Shankaran S, Ambalavanan N, et al. Characteristics of extremely low-birth-weight infant survivors with unimpaired outcomes at 30 months of age. J Perinatol. 2013; 33: 800-805.

[19] Nagy A, Beke AM, Gráf R, et al. Development and its predictive factors in extremely low birth weight infants. [Extrém kis súlyú koraszülöttek kisgyermekkori fejlődése és a fejlődés háttértényezői.] Alkalm. Pszichol. 2017; 17: 37-56. [Hungarian]

[20] Szele A, Nagy BE. The connection between maltreatment and preterm birth - in the light of psychomotor development at 2 years old. [A bántalmazás és a koraszülés összefüggései a kétéves kori pszichomotoros fejlődés tükrében.] Orv Hetil. 2017; 158: 976-983. [Hungarian]

[21] Voss W, Neubauer AP, Wachtendorf M, et al. Neurodevelopmental outcome in extremely low birth weight infants: what is the minimum age for reliable developmental prognosis? Acta Paediatr. 2007; 96: 342-347.

[22] Marret S, Marchand-Mertin L, Picaud JC, et al. Brain injury in very preterm children and neurosensory and cognitive disabilities during childhood: The EPIPAGE cohort study. PloS ONE 2013; 8: e62683.

[23] Kalmár M. Predictability and unexpected turns in the development of intelligence. Implications of a follow-up study of nonrisk and preterm children. $[\mathrm{Az}$ intelligencia alakulásának előrejelezhetősége és váratlan fordulatai. Rizikómentesen született, valamint koraszülött gyermekek követésének tanulságai.] ELTE Eötvös Kiadó, Budapest, 2007. [Hungarian]

[24] Hutchinson EA, De Luca CR, Doyle LW, et al. School-age outcomes of extremely preterm or extremely low birth weight children. Pediatrics 2013; 131: e1053-e1061.

[25] Cserjesi R, Van Braeckel KN, Butcher PR, et al. Functioning of 7-year-old children born at 32 to 35 weeks' gestational age. Pediatrics 2012; 130: e838-e846. 
[26] Xiong T, Gonzalez F, Mu DZ. An overview of risk factors for poor neurodevelopmental outcome associated with prematurity. World J Pediatr. 2012; 8: 293-300.

[27] Salas AA, Carlo WA, Ambalavanan N, et al. Gestational age and birthweight for risk assessment of neurodevelopmental impairment or death in extremely preterm infants. Arch Dis Child Fetal Neonatal Ed. 2016; 101: F494-F501.

[28] Goldstein RF, Cotton CM, Shankaran S, et al. Influence of gestational age on death and neurodevelopmental outcome in premature infants with severe intracranial hemorrhage. J Perinatol. $2013 ; 33: 25-32$.

[29] Guerra CC, de Moraes Barros MC, Goulart AL, et al. Premature infants with birth weight of 1500-1999 g exhibit considerable delays in several developmental areas. Acta Paediatr. 2014; 103: $1-6$.

[30] Singer LT, Siegel AC, Lewis B, et al. Preschool language outcomes of children with history of bronchopulmonary dysplasia and very low birth weight. J Dev Behav Pediatr. 2001; 22: 1926.

[31] Schmidt B, Asztalos EV, Roberts RS, et al. Impact of bronchopulmonary dysplasia, brain injury, and severe retinopathy on the outcome of extremely low-birth-weight infants at 18 months: results from the trial of indomethacin prophylaxis in preterms. JAMA 2003; 289: 1124-1129.

[32] Gráf R, Boross G, Harnos A. Developmental speciality of preterm infants with bronchopulmonary dysplasia. [A bronchopulmonális dysplasiás koraszülöttek fejlődési sajátosságai.] Gyermekgyógy Továbbk Szle. 2013; 18: 25-29. [Hungarian]

[33] Kato T, Mandai T, Iwatani $S$, et al. Extremely preterm infants small for gestational age are at risk for motor impairment at 3 years corrected age. Brain Dev. 2016; 38: 188-195.

[34] Gortner L, Van Husen M, Thyen U, et al. Outcome in preterm small for gestational age infants compared to appropriate for ges- tational age preterms at the age of 2 years: a prospective study. Eur J Obstet Gynecol Reprod Biol. 2003; 110(Suppl 1): S93S97.

[35] Reis ABR, De Mello RR, Morsch DS, et al. Mental performance of very low birth weight preterm infants: assessment of stability in the first two years of life and factors associated with mental performance. Rev Bras Epidemiol. 2012; 15: 13-24.

[36] Kenyhercz F, Nagy BE. Examination of psychomotor development in relation to social-environmental factors in preterm children at 2 years old. [Koraszülött gyermekek kétéves kori pszichomotoros fejlődése társas-környezeti tényezők függvényében.] Orv Hetil. 2017; 158: 31-38. [Hungarian]

[37] Vekerdy Zs, Ittzésné Nagy B, Gallai M, et al. The Hungarian introduction of the Bayley Scales of infant development 2 nd edition. [A Bayley II.-csecsemőteszt magyarországi bevezetése.] Gyermekgyógyászat 1998; 49: 466-478. [Hungarian]

[38] Cardoso FG, Formiga CK, Bizinotto T, et al. Concurrent validity of the Brunet-Lèzine Scale with the Bayley Scale for assessment of the development of preterm infants up to two years. Rev Paul Pediatr. 2017; 35: 144-150.

[39] Ko G, Shah P, Lee SK, et al. Impact of maternal education on cognitive and language scores at 18 to 24 months among extremely preterm neonates. Am J Perinat. 2013; 30: 723-730.

[40] Weng YH, Yang CY, Chiu YW. Neonatal outcomes in relation to sex differences: a national cohort survey in Taiwan. Biol Sex Differ. $2015 ; 6: 30$.

(Nagy Anett, Budapest, Ecseri út 3., 1097 e-mail: anett.barczi@gmail.com)

\title{
MEGHÍ Vó
}

\section{A Szent János Kórház és Észak-budai Egyesitett Kórházak Tudományos Bizottsága}

\author{
tisztelettel meghivja az érdeklödőket a következő tudományos ülésére. \\ Időpont: 2018. október 18. (csütörtök) 14 óra \\ Helyszín: Szent János Kórház Auditóriuma - 1125 Budapest, Diós árok 1-3.
}

\section{Program:}

Prof. Dr. Palkovits Miklós: Az idegtudomány aktuális kérdései

Minden érdeklődőt szeretettel várunk.

A cikk a Creative Commons Attribution-NonCommercial 4.0 International License (https://creativecommons.org/licenses/by-nc/4.0) feltételei szerint publikált Open Access közlemény, melynek szellemében a cikk nem kereskedelmi célból bármilyen médiumban szabadon felhasználható, megosztható és újraközölhető, feltéve, hogy az eredeti szerző és a közlés helye, illetve a CC License linkje és az esetlegesen végrehajtott módosítások feltüntetésre kerülnek. 